\title{
Article
}

\section{Men procuring sexual services from women: everyman or peculiar man?}

\author{
Birch, Philip and Ireland, Jane Louise \\ Available at http://clok.uclan.ac.uk/12933/ \\ Birch, Philip and Ireland, Jane Louise ORCID: 0000-0002-5117-5930 (2015) \\ Men procuring sexual services from women: everyman or peculiar man? \\ Journal of forensic practice, 17 (1). pp. 13-20. ISSN 2050-8794
}

It is advisable to refer to the publisher's version if you intend to cite from the work. http://dx.doi.org/10.1108/JFP-03-2014-0007

For more information about UCLan's research in this area go to

http://www.uclan.ac.uk/researchgroups/ and search for < name of research Group>.

For information about Research generally at UCLan please go to http://www.uclan.ac.uk/research/

All outputs in CLoK are protected by Intellectual Property Rights law, including Copyright law. Copyright, IPR and Moral Rights for the works on this site are retained by the individual authors and/or other copyright owners. Terms and conditions for use of this material are defined in the policies page.

\section{CLoK}

Central Lancashire online Knowledge www.clok.uclan.ac.uk




Men procuring sexual services from women: everyman or peculiar man?

Philip Birch, Lecturer ${ }^{1}$

Jane L. Ireland, Professor and Research Lead ${ }^{2,3}$

Key Words: Prostitution; Sex workers; Sexual Health.

Word Count: 3,885

\section{IMPLICATIONS FOR PRACTICE}

- Markers for normality in procurement are indicated. Practitioners should avoid a focus on deviancy as a motivation.

- $\quad$ High proportions of those procuring were married and in professional employment, providing evidence of stability in aspects of presentation.

- Health professionals may have to prompt disclosure.

\footnotetext{
${ }^{1}$ School of Social Sciences and Psychology, University of Western Sydney, Australia.

${ }^{2}$ School of Psychology, University of Central Lancashire and Ashworth Research Centre, Mersey Care NHS Trust, UK

${ }^{3}$ Correspondence: J L Ireland, JLIreland1@uclan.ac.uk
} 


\section{ABSTRACT}

Objective: To explore characteristics of men procuring sexual services from women.

Design: Quantitative study using questionnaires and purposive sampling.

Setting: New South Wales, Australia including brothels and outreach organisations where sex worker is decriminalised.

Participants: 309 men who reported procuring sexual services with women.

Results: Primary motivations for procurement included thrill/excitement and attractiveness of the sex worker. Cluster analysis identified five groups, the most frequent being those with a drive for exciting, thrill-seeking sex with an attractive partner and those with the same drive but not wanting investment. High proportions of men were married, in professional employment and did not present with a criminal history. Sexual experiences procured were conventional. Procurement presented as an enduring behaviour maintained across decades, commencing at a young age. Involvement in procurement preceded decriminalisation.

Conclusion: The results do not support men's procurement as primarily 'deviant'.

Commonality of procurement and similarities across motivations lends support to the 'everyman' perspective. Professionals may need to explicitly enquire about such behaviour where relevant to do so (e.g. in discussing sexual health) and in doing so ensure procurement is discussed as normative and not as unusual behaviour. 


\section{INTRODUCTION}

The perception of men who procure sexual services from women has an interesting history. Early teachings from medical science encouraged men not to have recreational sex with their wives owing to the risk of pregnancy and increased chance of death during childbirth. It further considered men to have poor control over their sexual drives. Consequently, men were considered unable to control their sexual urges and encouraged to satisfy these by using sex workers and as a means to prevent unwanted marital pregnancy, rape and sodomy ${ }^{1}$. Biological differences became key in understanding the procurement of sexual services. This was initially fostered by the work of Lombroso ${ }^{2}$ whose writings on deviancy in the late $18^{\text {th }}$ Century sought to demonstrate clear biological difference between 'deviant' and 'non-deviant individuals'. Sheldon ${ }^{3}$ was greatly influenced by Lombroso and applied the concept of biological differences to those who could be classified as deviant arguing that differences (i.e. with those classified as non-deviant) would be clearly evidenced in their body shape. McLeod's work ${ }^{4}$ of men who procure sexual services would suggest that these men had an endomorph body type sometimes described as a 'self indulgent' body type ${ }^{3}$ because sex was a commodity to them and they were purchasing sex because of their self indulgent nature.

These positions of 'deviancy' and 'biology' whilst conflicting, as the former proposed inherent responsibility for behaviour whereas the latter made men 'blameless' due to biological deficiencies over which they had no control; they do share the belief that there is something outside of normative expectations concerning men who procure sexual services. This is either on the grounds they are $\mathrm{ill}^{5}$ or 'deviant' in the context of displaying 'abnormal' behaviour driven by sexual health challenges ${ }^{6}$. This view of 'ill' or 'abnormality' was extended by factions within feminism, in particular Radical and Marxist feminists. This position holds an extreme view that all sexual services with sex workers represent 'violence' and exploitation. Such views consider sex workers as survivors or victims of the dominance 
of men ${ }^{7}$. Men procuring are cast in the role of abuser. The notion of men who procure sexual services as non-deviant without biological deficiencies has been proposed more recently by scholars who argue two perspectives - the 'peculiar man perspective' and the more healthy and adaptive "everyman perspective" ${ }^{8}$. The latter offers a more prosocial understanding. It is in keeping with sanctioned sex work where sex workers do not identify themselves as victims but equal participants in the trading of an economic commodity ${ }^{9,10}$.

Nevertheless, research and intervention focus has been on sex workers and not procurers. Research into the men who procure has been limited by small sample sizes ${ }^{11,12}$, a focus solely on qualitative methods ${ }^{13}$, and on countries where procurement is illegal. This has contributed to a non-representative sample, potentially furthering assertions made regarding biological, psychological, social and sexual deficits in these men ${ }^{8}$. However, such assertions may be based on conjecture and poor sampling. The current study attempted to explore this by acquiring a large sample of men reporting to procure sexual services from women from a population where procurement was decriminalised. It sought to redress the imbalance in the research towards qualitative-only sampling by employing quantitative methodology and purposive sampling. Its main focus was to examine shared motivational characteristics between the men to determine if there was support for the two core perspectives offered; everyman or peculiar man. Determining the validity of these distinctions is important regarding the approach taken towards them by professionals, including medical professionals; the importance of not assuming deviance and in recognising the challenges men face in disclosing unprompted procurement behaviour for fear of being labelled as deviant becomes essential. 


\section{METHODS}

Three hundred and nine men took part (age range 29 to 76 years, $\mathrm{M}=47.5, \mathrm{SD}=10.9$ ). The largest proportion was of Anglo Saxon/British/Irish background (57.9\%, $\mathrm{n}=179)$, followed by Western and Northern European $(9.4 \%, \mathrm{n}=29)$, North Asian $(5.8 \%, \mathrm{n}=18)$, Eastern European $(5.2 \%, \mathrm{n}=16)$, Southern European $(4.9 \%, \mathrm{n}=15)$ and South East Asian $(13 \%, \mathrm{n}=$ 41), with the remaining comprising North African and Middle East $(2.6 \%, n=8)$, Sub Saharan African $(0.6 \%, \mathrm{n}=2)$ and Aboriginal/Torres Strait Islander $(0.3 \%, \mathrm{n}=1)$.

The sample was recruited from New South Wales, Australia, where sex work has been decriminalised since 1995. This population was targeted as it was aimed to obtain a representative sample without participants fearing repercussions (e.g. criminal sanctions). Purposive sampling was utilised so only men who procured sexual services were sampled. Advertisements were placed in a newspaper article in the Sydney Morning Herald; (Sydney) Sex Worker Outreach Project (SWOP); Brothels; and Internet advertisements on 'Sensual Downunder' (an Australian online discussion forum used by men who purchase sex). The questionnaire was completed by all participants, either in hard copy and posted back to the researcher, or online. Choice was left to participants.

The questionnaire comprised questions focusing on demographics (e.g. age, occupation, marital status), age at which sexual services were first purchased, reasons for choosing to have sex with a sex worker, frequency of purchase, and relationship satisfaction with current partner. The questionnaire was developed following a review of research and in consultation with SWOP, involving input from support and sex workers to ensure validity. Data was analysed using descriptive statistics and hierarchical cluster analysis. 


\section{RESULTS}

A descriptive analysis of the men involved in procurement is presented first, followed by an analysis of motivation to procure. This includes a cluster analysis illustrating the motivations most typical for instigating initial and continuing use of sexual services. It expands into outlining the characteristics of the men within each cluster.

\section{Descriptive analysis of men procuring sexual services}

General characteristics: The largest proportion of men procuring sexual services listed their occupation as a senior professional group (professional group A: e.g. doctor, lawyer: $27.5 \%$, $\mathrm{n}=85$ ), followed by other professional groups (professional group B: e.g. media and marketing: $24.9 \%, \mathrm{n}=77)$. This was followed by white collar clerical $(15.5 \%, \mathrm{n}=48)$, skilled manual $(13.9 \%, \mathrm{n}=43)$, unskilled manual $(5.5 \%, \mathrm{n}=17)$, students $(5.8 \%, \mathrm{n}=18)$, those retired $(3.9 \%, \mathrm{n}=12)$, unemployed $(1.9 \%, \mathrm{n}=6)$ and those indicating themselves to be diplomats $(1 \%, \mathrm{n}=3)$.

Three hundred and eight men provided information on criminal convictions, with 92.9\% $(\mathrm{n}=286)$ reporting no criminal convictions. Of those reporting a criminal conviction $(\mathrm{n}=22), 20$ listed convictions graded as 'low seriousness' as defined by the Australian and New Zealand Standard offence Classification (e.g. driving whilst disqualified). The remaining two men reported serious offences occurring in the context of procurement (e.g. murder and attempted murder of a sex worker). Both indicated they had served time in prison for these offences.

Two hundred and sixty-one men indicated their relationship status: almost half listed their status as single $(45.6 \%, \mathrm{n}=119)$, with the remainder either married $(34.9 \%, \mathrm{n}=91)$, in a live-in relationship $(11.5 \%, \mathrm{n}=30)$, divorced $(7.7 \%, \mathrm{n}=20)$ or widowed $(0.4 \%, \mathrm{n}=1)$. 
Engagement in procurement: The average age of first procurement of sexual services was 25 $(\mathrm{SD}=8.5)$, with an age range of 12 to 69 and median of $22(\mathrm{IQR}=19$ to 28$)$. Two hundred and sixty-three men reported the location of where they first purchased a sexual service. The most common was an indoor market location $(85 \%, \mathrm{n}=223)$, with a brothel the most common of these $(51 \%, \mathrm{n}=134)$. The average length of time men had been procuring sexual services was 21 years $(\mathrm{SD}=12)$ and therefore prior to the decriminalisation of sex work. The sample could also be termed 'regular' clients of the sex work industry as almost $59 \%$ of the men who answered this question (based on $n=262$ ) stated they purchased sex weekly, fortnightly or monthly $(\mathrm{n}=154)$.

Nature of procurement: Two hundred and sixty two men outlined the nature of services purchased. The most commonly purchased was vaginal intercourse $(90 \%, \mathrm{n}=238)$, followed by oral intercourse $(77.1 \%, \mathrm{n}=202)$, hand relief $(51.9 \%, \mathrm{n}=136)$ and massage $(51.1 \% . \mathrm{n}=$ 134). Less conventional services were reported at a frequency of $26.7 \%(n=70)$ for "more than one sex worker', $24.2 \%(n=64)$ for anal intercourse and $11.5 \%(n=30)$ for a fetish.

Sexual satisfaction: Just over half the sample listed sexual satisfaction within their current relationship (based on $\mathrm{n}=141$ ) as 'fairly unsatisfied' or 'very unsatisfied' $(51 \%, \mathrm{n}=72)$. This was followed by $22.7 \%(\mathrm{n}=32)$ who reported satisfaction with relationship sex and $26.3 \%(n=37)$ who indicated they were 'fairly satisfied' or 'very satisfied'.

Disclosure of procurement to others: Two hundred and sixty men provided information on disclosure. Over half $(53.8 \%, \mathrm{n}=140)$ indicated they had disclosed, with $44.6 \%(\mathrm{n}=116)$ stating they never would, and the remaining $1.5 \%(\mathrm{n}=4)$ indicating they would like to disclose. Of the 140 men indicating they had disclosed, the majority did not indicate who 
they had informed $(79.3 \%, \mathrm{n}=111)$, with the remainder indicating friends $(12.1 \%, \mathrm{n}=17)$, wife, partner or mistress $(9.8 \%, \mathrm{n}=7)$, family members $(2.1 \%, \mathrm{n}=3)$, or others $(1.4 \%, \mathrm{n}=$ 2).

All participants were asked for the reasons which prevented their disclosure (to anyone or to specific others), therefore maintaining secrecy of their procurement. Two hundred and sixty participants provided reasons, with these most focused on feelings of shame and embarrassment $(36.5 \%, \mathrm{n}=95)$, followed by feeling there was a stigma attached to disclosure $(30 \%, \mathrm{n}=78)$, that family members or friends would stop talking to them $(23.5 \%, \mathrm{n}=61)$, or they would be labelled as a 'pervert or sad' $(17.3 \%, \mathrm{n}=45)$. Just under $15 \%$ of the sample felt that the disclosure of their engagement in procurement was not important enough to report $(14.6 \%, \mathrm{n}=38)$, with the smallest reported reason that of being considered unattractive by others if they knew of their procurement $(5.4 \%, \mathrm{n}=14)$.

Perceptions of procurement: The men were asked how they felt others, namely the general public, would view their behaviour. Five core perceptions were reported $(n=260)$; that the behaviour is deemed 'perverse/dirty' $(71 \%, \mathrm{n}=184)$, that they could 'not be trusted' $(37.1 \%$, $\mathrm{n}=96)$, that they are 'pathological/sick' $(26.6 \%, \mathrm{n}=69)$, and a 'danger' to others $(13.9 \%, \mathrm{n}$ =36). Over a quarter of the sample felt their behaviour would be perceived a luxury as part of a wealthy lifestyle $(27 \%, \mathrm{n}=70)$.

Procurement and decriminalisation: Men were asked if they would stop purchasing sexual services if it was re-criminalised in New South Wales. The majority of men indicated that they would not $(69.3 \%, \mathrm{n}=180)$ with only a small proportion of these $(8.3 \%, \mathrm{n}=15)$ reported that it would increase their sexual arousal to know they were engaging in a criminal 
act. Of the $30.7 \%(\mathrm{n}=80)$ who indicated they would cease procurement $37.5 \%(\mathrm{n}=30)$

indicated it would be conditional on the punishment.

\section{Motivations for procuring sexual services}

Two hundred and sixty two of the sample commented on motivations. They were invited to identify as many motivations as applied to them. Results are indicated in Table 1.

$<<$ Insert Table 1 here >>

A cluster analysis was performed. Cluster analysis is a statistical technique used on nominal levels of measurement to group individuals into clusters deemed to be homogenous. Hierarchical cluster analysis was used as it includes all cases in a dataset and progressively grouped until each participant is located in a group. The alternative type of cluster analysis, K-Means Cluster Analysis, was not appropriate for the current data as the researcher has to decide on the number of clusters to extract before carrying out the procedure and then has to force membership of individual cases. Hierarchical Cluster Analysis did pose the risk of generating a large number of clusters, reducing generalizability. The current data only generated five clusters, however, representing $100 \%$ of the sample. Table 2 presents the results of the Hierarchical Cluster Analysis.

$<<$ Insert Table 2 here $>>$

Five grouped motivations were apparent from the cluster analysis. The largest groups were almost equally split between those who had a drive for exciting, thrill-seeking sex with an attractive partner (cluster 1: 27\%) and those with a drive for exciting, thrill-seeking sex with 
attractive partner but no investment (cluster 3: 26\%). Positive motivators were thus indicated within both of the major clusters. The distinguishing feature was one of investing or not in the sexual contact. This was followed in frequency by a cluster that also had a drive for no commitment in the sexual activity but further reported the absence of regular sex (absence of regular sexual contact and drive for sex with no commitment: cluster 2, 20\%). The smallest clusters were men seeking intimacy (drive for intimacy: cluster 4, 16\%) and a drive for exciting, thrill-seeking sex that is detached (cluster 5, 11\%).

The motivations identified and classified clusters indicated evidence for positive motivations, best defined as a gratifying outcome. Negative motivations were less common, with these defined as a motivation driven by the absence of a factor in their intimate life, such as absence of regular sexual activity (cluster 2), absence of a partner and feelings of loneliness (cluster 4). Such clusters made up only one fifth of the sample. Cluster 4 (drive for intimacy) does appear to have positive aspects, however, since it is focused on acquiring intimacy with others. It is therefore distinguished from cluster two which is focused on the absence of regular sex and a need to replace this with a detached sexual experience. Cluster 2 could be argued as the only cluster therefore characterised entirely by negative motivators.

\section{Characteristics of clusters}

Table 3 presents the core characteristics of men involved in the procurement of sexual services across each cluster.

$<<$ Insert Table 3 here $>>$

Similarities in characteristics were noted across clusters. One of the main differences was found among the drive for intimacy (cluster 4) participants who were younger with fewer 
years' procurement. They were also more likely to be single. The drive for exciting, thrillseeking sex that is detached participants (cluster 5) were most likely to be married. Notably, approximately fifty percent of participants in the remaining clusters report they were married. Of further interest is the proportion of men informing others of their procurement with over half of clusters reporting this. The drive for intimacy cluster were the smallest proportion reporting they would stop procurement if it became illegal, with 55\% of this cluster reporting they would not desist. The remaining clusters all indicated a similar proportion of indicating their behaviour would continue even if it became illegal.

\section{DISCUSSION}

Motivations for procurement were located in five clusters. Only one cluster - absence of regular sexual contact and drive for sex with no commitment - could be described as negatively motivated since it was based on the absence of sexual activity and a need to replace this with a detached sexual experience. One quarter of the sample reported this motivation. When the clusters were mapped onto characteristics, a lack of deviance was indicated. This was suggestive of support for the everyman perspective as opposed to peculiar man perspective ${ }^{8}$. Markers of good functioning included an almost total absence of criminal convictions, only a very small proportion reporting that criminalising procurement would increase their sexual arousal, and procurers most commonly presenting in a professional, white collar or skilled employment group, a finding consistent with previous research $^{14,13}$. Such examples of characteristics do not support deviancy models.

The primary motivation for procurement focused on thrill/excitement and sex worker attractiveness. The latter has not been recorded as a motivation in previous research. There is a growing body of literature, however, reporting that men consider the 'girlfriend experience' a key motivator for procurement ${ }^{15,16}$. The current findings appear to lend some 
support to this, particularly when requiring intimacy is also indicated as a procurement motivation. An examination of services procured was primarily conventional, further refuting the notion of peculiarity ${ }^{6,5}$. The services sought were commonly associated with conventional sexual relationships ${ }^{15,17}$. Some indicators of deviancy were noted, however. These included procurement motivated by a desire to act out a fantasy/fetish (approximately a quarter of the sample), an absence of positive sexual experiences in their current relationship (approximately one fifth of the sample) and the potential to use sex toys (under a tenth of the sample). The extent to which these really represent a degree of deviancy are open to debate.

The length of time men have procured and the age at which this commenced (i.e. average length of time 21 years, median age at first commencement 22 years) is of interest. Age at first procurement reflects existing international literature ${ }^{18,19,20}$ suggesting the current sample is not atypical. Length of time procuring is considerable, however, and extends prior to the implementation of decriminalisation (1995). Thus the majority of the current sample engaged in procurement when this was criminalised. Procurement also appears not to have desisted when in a committed relationship, with almost half the sample reporting to be married or in a committed relationship. This is consistent with previous research ${ }^{21,22,19}$ ) and is arguably indication of deviancy in moral behaviour. Connected to this, approximately fifty percent of men indicated some degree of sexual dissatisfaction in their current sexual relationship, suggesting that the quality of the committed relationship was challenged.

It is also worth noting at this point the importance of disclosure. The majority of men reported they had informed others of their procurement although cited shame, rejection and stigma as key issues in presenting disclosure. Their perceptions of how procurement was viewed by others focused on the behaviour being considered sexually deviant or pathological. Such beliefs are not conducive to the full disclosure of procurement. This sample was taken from a population where the behaviour was decriminalised and yet negative perceptions 
remained prevalent. Thus the challenges these men face in reporting issues arising from their involvement with procurement needs to be acknowledged. This may include health issues, such as sexual health issues. The role of professionals in normalising procurement to aid disclosure becomes crucial. For example, discussion of procurement may need to be generated from the treating medical professional if sexual health issues arise. Education of professionals would need to include a focus on procurement not being restricted to individuals considered deviant ${ }^{7,8}$.

The study is not without limitations. The sample was self-selecting, an unavoidable limitation of purposive sampling. It also limited itself to men procuring women, not extending this to women procurers or same-sex procurement. Future research could examine a wider range of populations and sexual preferences. It could also examine stability of procurement motivations. The current study focused only on general motivations and not on how motivations may potentially adapt across the time of procurement. Nevertheless, the study indicates some initial observations of interest, refuting assertions that procurement is indicative of deviancy, focusing instead on the more normative and positive elements. The importance of professionals conveying this normative message when enquiring about behaviours that may associate with procurement becomes essential.

Contributors: PB designed and coordinated the study and completed the analyses. He cowrote the write up with JI. JI led with paper preparation and co-led results interpretation.

Funding: The research was not associated with any funding bodies or authorities.

Competing interests: None declared.

Ethical approval: The study was approved by the University of New South Wales, ethics committee.

Provenance and peer review: Not commissioned. Peer reviewed. 
Publishing Rights: The Corresponding Author has the right to grant on behalf of all authors and does grant on behalf of all authors, an exclusive licence on a worldwide basis to the BMJ Publishing Group Ltd to permit this article (if accepted) to be published in BMJ editions and any other BMJPGL products and sublicences such use and exploit all subsidiary rights, as set out in our licence.

Transparency: The manuscript is an honest, accurate, and transparent account of the study being reported. No important aspects of the study have been omitted. Any discrepancies from the study as planned (and, if relevant, registered) have been explained.

Data sharing and copyright: Data sharing is agreed. The data remains the property of the first author. The ideas within the paper remain the intellectual property of both authors. 
Table 1

Motivations for procuring sexual services $(n=262,47 \mathrm{msg})$ presented in rank order of frequency.

\begin{tabular}{lcc}
\hline Motivation reported in rank order* & $\mathrm{N}$ & $\%$ \\
\hline Thrill/excitement (1) & 142 & 54.2 \\
Attractiveness of sex worker (2) & 138 & 52.7 \\
Devoid of all responsibility (3) & 108 & 41.2 \\
Because I am single (4) & 103 & 39.3 \\
Non emotional sex (5) & 97 & 37 \\
Don't have regular sex with a partner (6) & 89 & 34 \\
Lonely (7) & 88 & 33.6 \\
Live out a fantasy/fetish (8) & 72 & 27.5 \\
Cheaper than a date (9) & 56 & 21.4 \\
Don't have good sex with partner (10) & 49 & 18.7 \\
To be able to use sex toys (11) & 17 & 6.5 \\
\hline
\end{tabular}

*NB: more than one response could be indicated 
Table 2

Motivations for procuring sexual services: Cluster Analysis $(N=292,47 m s g)$

Cluster Group $\quad$ Main Motivations $\%$ of overall sample
(number) Label

(number) Label

(1) Drive for exciting, thrill-seeking sex

Attractiveness

27

with attractive partner

Thrill/Excitement

(2) Absence of regular sexual contact and

Devoid of all

20

drive for sex with no commitment

responsibility,

No regular sex with

partner

(3) Drive for exciting, thrill-seeking sex

Devoid of all

26

with attractive partner but no investment

responsibility

Non emotional sex

Living out a fantasy

Thrill/Excitement

Attractiveness

(4) Drive for intimacy

Single

16

Loneliness

Attractiveness

(5) Drive for exciting, thrill-seeking sex

Thrill/Excitement

that is detached

Living out a Fantasy

Non emotional sex 
Table 3

Characteristics of men involved in procuring sexual services $(N=292,47 \mathrm{msg})$

\begin{tabular}{|c|c|c|c|c|c|c|c|c|}
\hline Cluster Group (number) & $\begin{array}{l}\text { Age } \\
\text { (M) }\end{array}$ & $\begin{array}{c}\text { Primary } \\
\text { occupational } \\
\text { status }\end{array}$ & $\begin{array}{c}\text { Age } \\
\text { commenced }\end{array}$ & $\begin{array}{c}\text { No. of } \\
\text { years } \\
\text { procuring }\end{array}$ & $\begin{array}{c}\text { Marital } \\
\text { status } \\
\text { (Mode) }\end{array}$ & $\begin{array}{l}\text { Frequency } \\
\text { (Mode) }\end{array}$ & $\begin{array}{c}\text { Told } \\
\text { others? }\end{array}$ & Stop if illegal? \\
\hline $\begin{array}{l}\text { Drive for exciting, thrill-seeking } \\
\text { sex with attractive partner (1) }\end{array}$ & 49 & $\begin{array}{l}\text { Professional } \\
\text { A }\end{array}$ & 23 & 26 & $\begin{array}{l}\text { Married/ } \\
\text { De facto } \\
49.3 \%\end{array}$ & $\begin{array}{l}2 \text { wks or } \\
\text { monthly } \\
21.4 \%\end{array}$ & $\begin{array}{c}\text { No } \\
53.5 \%\end{array}$ & $\begin{array}{c}\text { No } \\
73.3 \%\end{array}$ \\
\hline $\begin{array}{l}\text { Absence of regular sexual } \\
\text { contact and drive for sex with } \\
\text { no commitment ( } 2 \text { ) }\end{array}$ & 50 & $\begin{array}{l}\text { Professional } \\
\text { B }\end{array}$ & 24 & 26 & $\begin{array}{l}\text { Married/ } \\
\text { De facto } \\
52.9 \%\end{array}$ & $\begin{array}{c}\text { Every 3-6 } \\
\text { months. } \\
26.4 \%\end{array}$ & $\begin{array}{c}\text { No } \\
57.7 \%\end{array}$ & $\begin{array}{c}\text { No } \\
69.2 \%\end{array}$ \\
\hline $\begin{array}{l}\text { Drive for exciting, thrill-seeking } \\
\text { sex with attractive partner but } \\
\text { no investment ( } 3 \text { ) }\end{array}$ & 48 & $\begin{array}{l}\text { Professional } \\
\quad \text { B }\end{array}$ & 21 & 27 & $\begin{array}{l}\text { Married/ } \\
\text { De facto } \\
50 \%\end{array}$ & $\begin{array}{l}\text { Monthly } \\
26.5 \%\end{array}$ & $\begin{array}{l}\text { Yes } \\
61.8 \%\end{array}$ & $\begin{array}{l}\text { No } \\
75 \%\end{array}$ \\
\hline Drive for intimacy (4) & 40 & $\begin{array}{l}\text { Professional } \\
\text { A }\end{array}$ & 24 & 16 & $\begin{array}{l}\text { Single } \\
79.4 \%\end{array}$ & $\begin{array}{l}\text { Monthly } \\
27.7 \%\end{array}$ & $\begin{array}{l}\text { Yes } \\
67.4 \%\end{array}$ & $\begin{array}{l}\text { No } \\
55.8 \%\end{array}$ \\
\hline $\begin{array}{l}\text { Drive for exciting, thrill-seeking } \\
\text { sex that is detached (5) }\end{array}$ & 51 & $\begin{array}{l}\text { Professional } \\
\text { B }\end{array}$ & 22 & 29 & $\begin{array}{c}\text { Married/ } \\
\text { De facto } \\
84.6 \%\end{array}$ & $\begin{array}{l}\text { Every } 2 \\
\text { months } \\
33.3 \%\end{array}$ & $\begin{array}{c}\text { Yes } \\
53.8 \%\end{array}$ & $\begin{array}{c}\text { No } \\
65.3 \%\end{array}$ \\
\hline
\end{tabular}




\section{References}

${ }^{1}$ Brooks-Gordon B. The price of sex: Prostitution, policy \& society. Cullumpton: Willan Publishing, 2006.

${ }^{2}$ Lombroso C. Criminal man, translated by M. Gibson, H.N. Rafter. New York: Praeger, 2007.

${ }^{3}$ Sheldon WH. Varieties of delinquent youth: An introduction to constitutional psychiatry. New York: Harper Brothers, 1947.

${ }^{4}$ McLeod E. Women working: Prostitution now. London: Croom Helm, 1982

${ }^{5}$ Stroller RJ. Perversion: The erotic form of hatred. New York: Pantheon, 1975.

${ }^{6}$ Winick C. Prostitutes' client's perception of the prostitute and of themselves. International Journal of Social Psychiatry 1962; 8:289-297.

${ }^{7}$ Jeffreys S. The idea of prostitution. Melbourne: Spinifex Press, 1997.

${ }^{8}$ Monto MA, McRee JN. A comparison of the male customers of female street prostitutes with national samples of men. International Journal of Offender Therapy and Comparative Criminology 2005; 49: 505-529.

${ }^{9}$ Perkins R. Working girls: Prostitutes, their life and social control. Canberra: Australian Institute of Criminology, 1991.

${ }^{10}$ Sanders T, O'Neill M, Pitcher J. Prostitution: Sex work, policy and politics. London: Sage, 2009.

${ }^{11}$ Weitzer R. New directions in research on prostitution. Crime, Law and Social Change 2005; 43: 211-235.

${ }^{12}$ Weitzer R. Sociology of sex work. Annual Review of Sociology 2009; 35: 213-234.

${ }^{13}$ Wilcox A, Christmann K, Rogerson M, Birch P. Tackling the demand for prostitution: A rapid evidence assessment of the published research literature. London: HMSO, 2009. 
${ }^{14}$ Faugier J, Cranfield S. Reaching male clients of female prostitutes: The challenge for HIV Prevention. AIDS Care 1995; 7: S21-S32.

${ }^{15}$ Sanders T. Male sexual scripts: Intimacy, sexuality and pleasure in the purchase of commercial sex. Sociology 2008; 42: 400-417.

${ }^{16}$ Coy MH, Horvath M, Kelly L. It's just like going to the supermarket: men buying sex in East London. London: Child and Woman Abuse Studies Unit, London Metropolitan University, 2007.

${ }^{17}$ Milrod C, Weitzer R. The intimacy prism: Emotional management amongst the clients of escorts. Men and Masculinities 2012; 15: 447-467.

${ }^{18}$ Monto MA. Focusing on the clients of street prostitutes: A creative approach to reducing violence against women. Report submitted to the National Institute of Justice, 2000. Award Number: 97-IJ-CX-0033.

${ }^{19}$ Lowman J, Atchison C. Men who buy sex: a survey in the Greater Vancouver regional district. The Canadian Review of Sociology and Anthropology 2006; 43:281-296.

${ }^{20}$ Macleod J, Anderson L, Golding J. Challenging men's demand for prostitution in Scotland: A research report based on interviews with 110 men who bought women in prostitution. Glasgow: Women's Support Project, 2008.

${ }^{21}$ Sawyer S, Metz M, Hinds J, Brucker R. Attitudes towards prostitution among males: A 'consumers' report'. Current Psychology 2001;20: 363-376.

${ }^{22}$ Kennedy MA, Klein C, Gorzalka BB, Yuile JC, Attitude change following a diversion program for men who solicit sex. Journal of Offender Rehabilitation 2004;40:41-60. 